\title{
Previously Treated Childhood Rhabdomyosarcoma
}

National Cancer Institute

\section{Source}

National Cancer Institute. Previously Treated Childhood Rhabdomyosarcoma. NCI

Thesaurus. Code C115332.

A childhood rhabdomyosarcoma for which a patient has received treatment in the past. 